\title{
A Case of Nasopharyngeal Papillary Adenocarcinoma: Nasal Endoscopic Approach
}

\author{
Byung Wook Yang, Min Ju Park and Byung Hoon Ahn \\ Department of Otorhinolaryngology, School of Medicine, Keimyung University, Daegu, Korea \\ 비인두 유두상 선암종의 비내시경적 치료 1예 \\ 양병욱 · 박민주 · 안병훈 \\ 계명대학교 의과대학 이비인후과학교실
}

Received January 5, 2011

Revised March 2, 2011

Accepted March 2, 2011

Address for correspondence

Byung Hoon Ahn, MD

Department of Otorhinolaryngology,

School of Medicine,

Keimyung University,

216 Dalseong-ro, Jung-gu,

Daegu 700-712, Korea

Tel $+82-53-250-7715$

Fax $+82-53-256-0325$

E-mail bhahn@dsmc.or.kr
Low-grade nasopharyngeal papillary adenocarcinoma is an unusual nasopharyngeal tumor. This malignant tumor originates in the epithelium and exhibits adenocarcinomatous differentiation and indolent behavior. Macroscopically, these tumors are pedunculated polypoid masses that arise on the roof of the nasopharynx. Microscopically, they are characterized by papillary and glandular epithelial proliferation. We report a case of a 25 -year-old woman who presented with a papillary adenocarcinoma on the roof of nasopharynx; in describing the case, we have focused on the histological features and endoscopic management of the tumor. The tumor was completely excised via nasal endoscopic approach. Immunohistochemical analysis of the tumor was performed based on a differential diagnosis of metastatic papillary thyroid carcinoma. The testing involved thyroid transcription factor-1, thyroglobulin, and epithelial membrane antigen analysis. The patient remained disease-free for over 6 months after the surgical excision performed via nasal endoscopic approach.

Korean J Otorhinolaryngol-Head Neck Surg 2011;54:423-6

Key Words Papillary adenocarcinoma $\cdot$ Nasopharynx $\cdot$ Nasal endoscope.

\section{서 론}

비인두에서 발생하는 악성 종양은 발병률이 전세계적으로 10 만명당 1 명 이하로 드문 암이다.1) 조직학적으로 상피세포암 종이 비인두 악성 종양 중 가장 흔한 것으로 알려져 있으며 아 주 드물게 비인두 상피가 선암변성을 일으키면서 선암종이 발 생하기도 한다. ${ }^{2)}$ 저악성도 유두상 선암종이 이에 해당되며 장 액-점액선에서 발생하는 선암종과는 병리-면역 조직학적으로 구별이 된다. ${ }^{3-6)}$

국내 증례로 보고된 비인두 저악성도 유두상 선암종은 경구 강 접근법을 통한 치료 1 예가 전부였고,") 비내시경적 접근법을 통한 치료증례는 아직 보고된 바가 없다. 저자들은 25세 여성 환자의 비인두에 발생한 유두상 선암종 1예를 비내시경적 접 근을 통해 치험하였기에 문헌 고찰과 함께 보고하는 바이다.

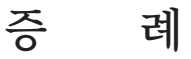

해외에 거주하던 25세 여자로 좌측 비출혈을 주소로 비중격 후부 종물이 관찰되어 시행한 조직검사 결과, 비인두 저악성 도 유두상 선암종 소견을 보여 본원 이비인후과를 방문하였 다. 환자 과거력 및 가족력상 특이 소견은 없었으며, 이학적 소 견상 좌측 비중격 후부와 비인두 상부에 걸쳐 약 $0.5 \times 0.5 \mathrm{~cm}$ 크기의 비교적 규칙적인 경계의 유경성 종물과 이와 비슷한 크 기의 낭종성 종물이 약 $1 \mathrm{~cm}$ 뒤쪽으로 비인두 후벽에서 관찰 되었다. 그 외 비강과 부비강내 특이소견은 관찰되지 않았다. 본원에서 시행한 부비동 및 비인두 자기공명영상 검사상 T1WI 에서 저신호, T2WI에서 고신호 소견을 보이는 $0.5 \mathrm{~cm}$ 크기의 병변이 비인두 상부에 접하여 좌측 비중격 후부에서 관찰되 었고(Fig. 1), 비인두 후벽의 전이 및 병변의 범위 확인을 위 
해 시행한 PET CT 검사상 전이 소견은 보이지 않았다. 전신 마취하에 비내시경을 통한 광범위 절제술을 시행하였다. Sickle knife와 No. 15 blade를 이용하여 종물의 변연부와 2 3 mm 가량의 안전 영역을 확보한 후 점막을 절개하였으며, 하방골막을 포함하여 종물을 제거한 후 서골 일부가 노출 되 었으나 골파괴 및 골전이를 시사할 만한 특이 소견은 없었다. 수술 당시 시행한 동결절편 검사상 비인두 후벽의 낭종은 임 파양 조직(lymphoid tissue), 절제연은 종양이 포함되지 않은
것을 확인하였다. 술 후 제거된 종물은 Hematoxylin \& Eo$\sin$ 염색에서 수지상 배열을 보이며, 분비선의 형태는 체 모 양(cribriform)을 나타내었다(Fig. 2). 확진을 위한 면역화학 조직 검사상 $\mathrm{TTF}-1$ (thyroid transcription factor-1) 양성, EMA(epithelial membrane antigen) 양성, thyroglubulin 음성 으로, 저악성도 유두상 선암종(papillary adenocarcinoma, low grade) 소견을 보였다(Fig. 3). 환자는 종양 절제 후 재발 및 합병증 없이 6 개월째 외래 추적관찰 중이며, 수술 부위는
Fig. 1. MR Image demonstrated a 5 $\mathrm{mm}$ sized nonspecific mass at the left posterior end of the nasal septum, near the junction of the roof of the nasopharynx (arrow). The mass is hypointense on T1WI (A) with subtle heterogeneous enhancement, and hyperintense on T2WI (B).

Fig. 2. Hematoxylin and Eosin staining shows papillary mass with distinct fibrovascular cores $(\times 200, A)$. The tumor cells are colummar and have elongated nuclei. Definite nucleus pseudoinclusion is absent $(\times 400, B)$.

Fig. 3. Immuno-histochemical stain shows that epithelial cells are immunoreactive for TTF-1, which usu- 1 ally positive in thyroid follicular cells and papillary thyroid carcinoma in thyroid gland $(\mathrm{A})$. But tumor cells are not stained for TG (B). TTF-1: thyroid transcription factor, TG: thyroglobulin.
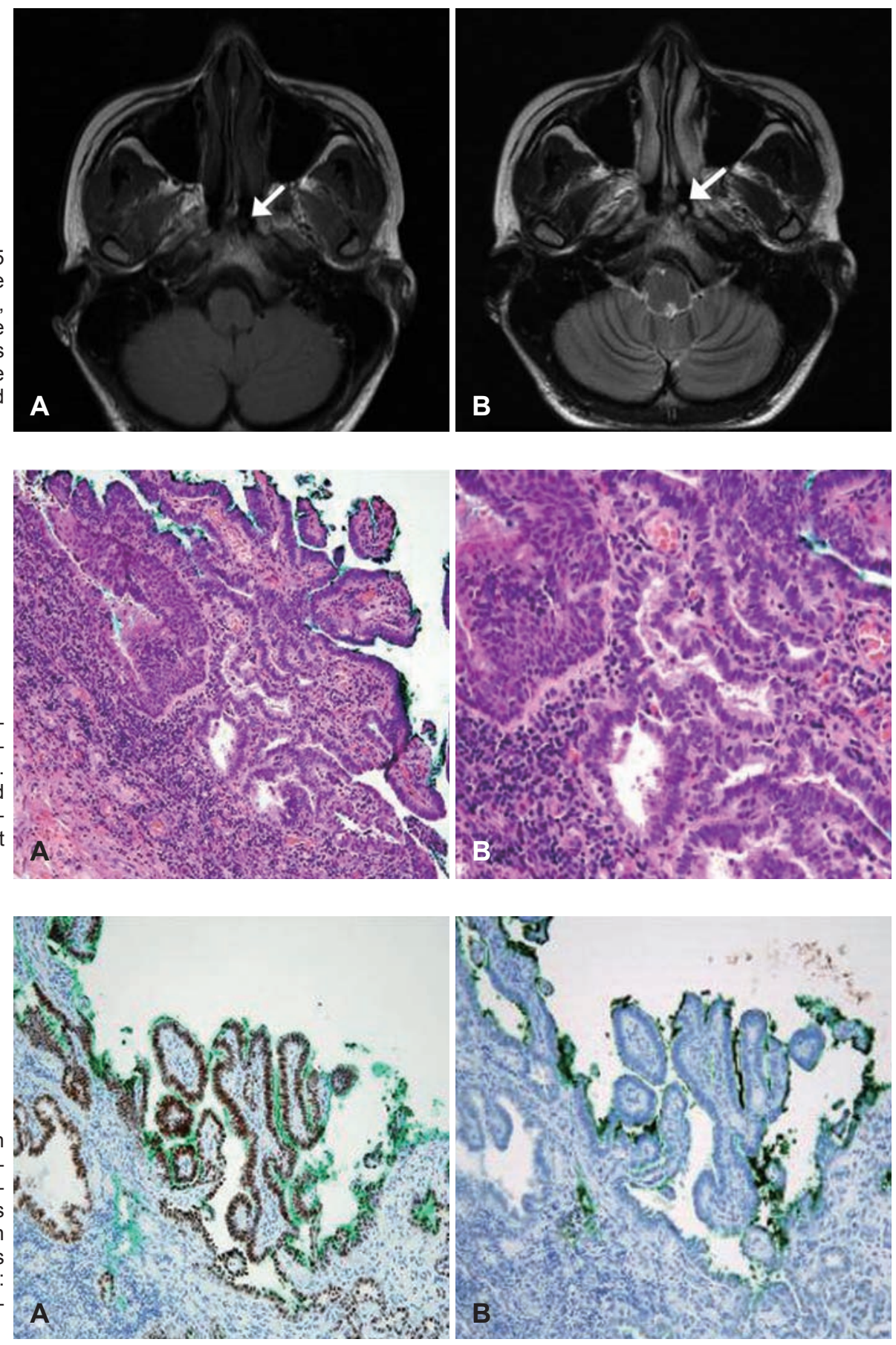
Fig. 4. A telescopic view shows 5 $\mathrm{mm}$ sized pedunculated mass (arrow) at posterior nasal septum contiguous with nasopharyngeal roof. Posterior nasopharyngeal wall lymphoid tissue (arrowhead) is already excised (A). Post operative (6 month), photograph shows that previous mass lesion was excised clearly, and the lesion was completely epithelialized with no lesion of recurrance $(B)$.
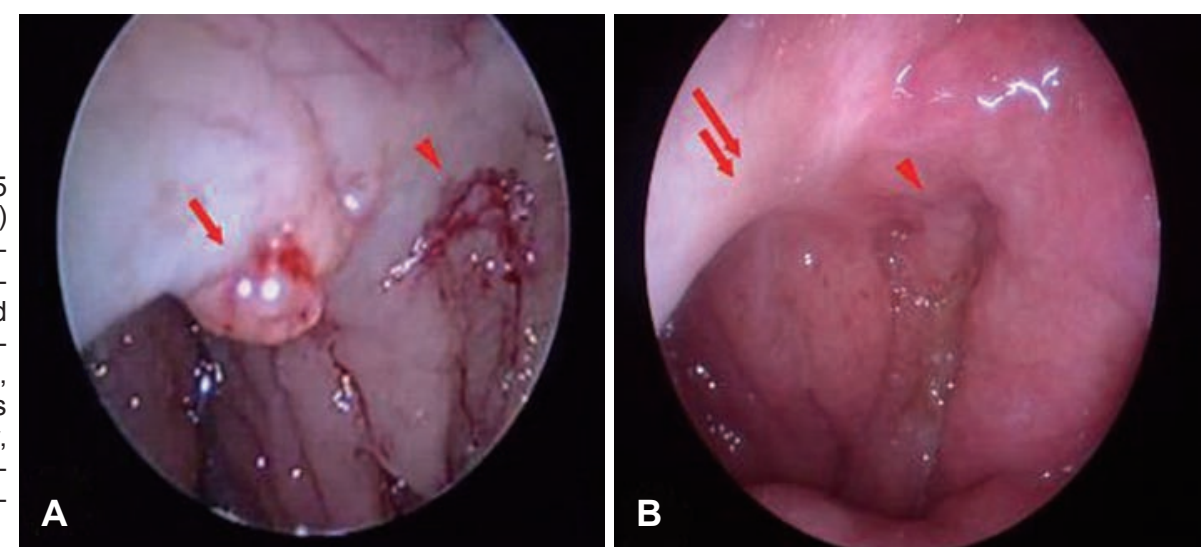

정상점막으로 잘 치유된 상태이다(Fig. 4).

\section{고 찰}

$\mathrm{WHO}(2005)$ 분류에 따르면 비인두의 상피성 악성종양은 비인두암종, 비인두 유두상 선암종, 타액선 기원의 암종 등 세 가지로 분류된다. 이 중 유두상 선암종은 비인두 표면 상피에 서 기원하며, 저악성도를 보인다. 비인두의 저악성도 유두상 선암종은 선암종 중에서도 드문 유형으로 비강내 원발성 종 양의 4 8\%를 차지한다. ${ }^{2,4)}$ 발병률은 남녀 동일하고, 대체로 40 80세에서 나타나며, 인종별로 차이는 없는 것으로 알려 져 있다. ${ }^{3)}$ 비인두의 저악성도 유두상 선암종의 정확한 병인은 알려져 있지 않고, 비인두의 어느 부위에서나 생길 수 있으나 주로 비인두의 후벽에 발생하는 것으로 알려져 있다. ${ }^{6}$

대부분의 비인두암종이 외측 비인두에 주로 발생하고 무 경성이며 림프절 전이가 흔한 데 비해, 저악성도 유두상 선암 종의 경우는 대체로 유경성이며, 림프절 전이는 드물다. ${ }^{8)}$

저악성도 유두상 선암종은 임상적으로 외장성의 유두상, 결절성 모양을 띄고 크기는 수 $\mathrm{mm}$ 에서 $3 \mathrm{~cm}$ 이내여서 비강 용종과 같은 양성 종양으로 오인 할 수 있어,5) 이학적 검사 및 임상양상만으로는 양성 선종과 구별하기 힘들며 반드시 조직학적 진단이 필요하다. 타액선 기원의 유두상 선암종과 조직학적으로 유사하지만, ${ }^{29}$ 타액선 유래 종양이 피막에 둘 러싸여 점막하에 존재하는 반면 유두상 선암종은 정상 상피 와 이어지면서 이행부가 존재하는 양상을 보인다. 그리고 다 른 비인두암종과 구별하기 위해 반드시 TTF-1, EMA 등의 면역조직화학 염색을 시행하여야 한다. ${ }^{34)}$ 또한 비인두 유두 상 암종은 갑상선 유두상 암종과 세포형태학적으로 유사성 을 보여 갑상글로불린에 대한 면역염색을 시행하여 갑상선 기 원이 아님을 확인해야 한다. 본 증례에서는 TTF-1, EMA 면 역조직화학 염색 2가지 모두에 양성반응을 보여 비인두 상피 에서 기원했다는 것을 시사하였으며, 갑상 글로불린 면역염
색 검사에서 음성반응을 보여 비인두 유두상 암종으로 진단 할 수 있었다.

환자들은 대개 수주에서 수개월에 걸친 비폐색이나 빈번한 비출혈을 주소로 내원하게 되며, 특이한 증상은 없다. 본 증례 의 환자 역시 빈번한 비출혈을 주소로 처음 이비인후과를 방 문하였었고, 본원 내원 당시에 특이 증상은 없었다.

치료는 종양의 적절한 절제가 원칙으로 알려져 있으며,7) 비인두는 해부학적으로 수술적 접근이 쉽지 않지만, 유경성 의 저악성도 유두상 선암종은 비내시경을 통해 절제 및 조직 검사가 가능하다. 국내 문헌에서 1 예가 보고되었는데, 진단 당 시 비중격 후부와 비인두 연결부위의 천장에 $0.5 \mathrm{~cm}$ 크기로 본 증례와 유사한 위치와 크기를 보였으나 경구개 접근법을 통한 절제술을 시행하였다. ${ }^{7)}$ 본 증례에서 시행하였던 비내시 경적 접근법의 경우 종양의 크기나 위치에 따라 충분한 시야 확보가 어려운 단점이 있으나, 경구개 접근법에 비해 비과 수 술이 익숙한 수술의에게 비교적 용이한 술기와 정확한 안전 영역 확인이 가능한 장점이 있어 수술 전 이학적 검사와 영상 의학적 검사를 통한 적절한 수술법을 결정해야 한다. 수술적 접근법에 관하여는 $\mathrm{Wu}$ 등 ${ }^{10}$ 과 Castelnuovo 등 ${ }^{11)}$ 이 비내시경 적 접근법을 통한 절제를 보고한 바가 있으나 아직 이에 대한 보편적 접근법으로 알려진 방식이 없으며, 유두상 선암종을 포함한 비인두 악성 종양의 비내시경적 수술은 Chen 등리 이 $\mathrm{AJCC}$ 병기분류상 종양이 $\mathrm{T} 1-2 \mathrm{a}$ 에 해당할 경우, 즉 종양이 비인두에 국한된 경우나, 구인두 혹은 비강내로 자라 들어갔 으나 부인두공간 침범이 없을 때에 비내시경적 치료만으로 6 명의 환자 중 5 명이 완치되었고 나머지 1 명은 수술 후 방사선 치료를 추가적으로 시행하여 완치되었다고 보고한 바 있다.

비인두 유두상 선암종은 비인두암종 중 흔하게 접하게 되 는 상피세포암종이나 타액선 기원 암종에 비해 드물게 발생하 므로 진단 초기의 정확한 감별진단이 필요하며, 적절한 수술 적 절제가 이루어질 경우 더 좋은 예후를 기대할 수 있다. 수 술적 절제를 위한 접근 방식에 대해 알려진 보편적인 방식은 
아직 없으나, 경우에 따라 비내시경을 통한 치료도 가능하며 유용할 수 있을 것으로 사료된다.

\section{REFERENCES}

1) Lee YS. Nasopharyngeal tumors. In: Korean Society of Otorhinolaryngology Head and Nect Surgery. Otolaryngology-Head and Neck surgery. $2^{\text {nd }}$ ed. Seoul, Korea: Ilchokak; 2009. p.1648-58.

2) Pineda-Daboin K, Neto A, Ochoa-Perez V, Luna MA. Nasopharyngeal adenocarcinomas: a clinicopathologic study of 44 cases including immunohistochemical features of 18 papillary phenotypes. Ann Diagn Pathol 2006;10(4):215-21.

3) Wenig BM, Hyams VJ, Heffner DK. Nasopharyngeal papillary adenocarcinoma. A clinicopathologic study of a low-grade carcinoma. Am J Surg Pathol 1988;12(12):946-53.

4) Van Hasselt CA, Ng HK. Papillary adenocarcinoma of the nasopharynx. J Laryngol Otol 1991;105(10):853-4.

5) Wenig BM, Pilch BZ. Tumors of the upper respiratory tract. In: Fletcher CDM, editor. Diagnostic histopathology of tumors. 2nd ed. New York: Churchill Livingstone; 2000. p.87-169.

6) Ohe C, Sakaida N, Tadokoro C, Fukui H, Asako M, Tomoda K, et al. Thyroid-like low-grade nasopharyngeal papillary adenocarci- noma: report of two cases. Pathol Int 2010;60(2):107-11.

7) Lee SJ, Chung PS, Lim ES, Kwon MS. A case of low-grade papillary adenocarcinoma of the nasopharynx. Korean J OtolaryngolHead Neck Surg 2005;48(7):937-9.

8) $\mathrm{Fu} \mathrm{CH}$, Chang KP, Ueng SH, Wu CC, Hao SP. Primary thyroidlike papillary adenocarcinoma of the nasopharynx. Auris Nasus Larynx 2008;35(4):579-82.

9) Sillings CN, Weathers DR, Delgaudio JM. Thyroid-like papillary adencarcinoma of the nasopharynx: a case report in a 19-year-oldmale. Oral Surg Oral Med Oral Pathol Oral Radiol Endod 2010;110(3): e25-8.

10) Wu PY, Huang CC, Chen HK, Chien CY. Adult thyroid-like lowgrade nasopharyngeal papillary adenocarcinoma with thyroid transcription factor-1 expression. Otolarygol Head Neck Surg 2007;137 (5):837-8.

11) Castelnuovo P, Dallan I, Bignami M, Battaglia P, Mauri S, Bolzoni Villaret A, et al. Nasopharyngeal endoxcopic resection in the management of selected malignancies : ten-year experience. Rhinology 2010;48(1):84-9

12) Chen MK, Lai JC, Change CC, Liu MT. Minimally invasive endoscopic nasopharyngectomy in the treatment of recurrent T1-2a nasopharyngeal carcinoma. Laryngoscope 2007;117(5):894-6. 